\title{
THE INFLUENCE OF HUMAN RESOURCES ON THE INCOME OF SMALL AND MEDIUM ENTERPRISES IN GALANG DISTRICT OF DELI SERDANG REGENCY (Case Study of Rumah Makan Tenda Biru)
}

\author{
Sayang Khairani ${ }^{1}$; Rahmat Suryanto Pirngadi ${ }^{2}$ \\ ${ }^{12}$ Universitas Nahdlatul Ulama Sumatera Utara, Indonesia \\ ${ }^{2}$ rahmat87pirngadi@gmail.com
}

\begin{abstract}
Rumah Makan Tenda Biru one of the largest restaurants in Galang district of Deli Serdang district, this restaurant provides Javanese and typical Minang cuisine. This business continues to grow over time, where at the beginning of the establishment of the building is only a small tent, and at this time already has a large building. The purpose of this study is to look at the influence of human resources on the income of Blue House, what problems are faced, and analyze consumer behavior. The results showed that, the location of human resources is very influential on the income of small and medium-sized businesses, by employing employees of graduates of High School (SMA) this business is able to reap profits of Rp. 105.000.000/month or Rp. 3.500.000 per day, when compared to when their employees graduated from Junior High School (SMP), the turnover obtained was only 60.000.000/month. In the time of the pandemic, there was a decrease in income, where before the pandemic profits reached Rp. 135.000.000/month. The obstacle experienced is the high PPH burden and must be paid every year for Rp 10.500.000. An analysis of consumer behavior states that $48 \%$ of consumers choose food as the main reason to visit the Tenda Biru Restaurant, 25\% choose cleanliness, 15\% choose service and 12\% choose a vehicle parker place.
\end{abstract}

Keywords: Human Resources, Income, Small and Medium Enterprises, Consumer Behavior

\section{A. Introduction}

Human resources have two different meanings. First, human resources are a work or service business that is indeed provided with the aim of carrying out the production process. The second understanding of HR is where humans are able to work to produce a service or goods from their work business. (Sumarsono, 2003, p. 4) 
Human resources (HR) are the driving force of the organization or company, if $H R$ is not managed properly and correctly to be able to work together and synergize with each other, it is impossible for the organization or company to run well and maximally as expected, but What must be understood and understood is that humans are not like machines that work without feeling and are considered solely as a source of business energy, but humans as living beings who have perfect taste, creativity and intention as God's creatures. (Elbadiansyah, 2019, pp. 2-4)

The role of Human Resources management is to determine the number, quality and placement of an effective workforce in accordance with the needs of the company based on the parts of the job. (Hasibuan, 2003, p. 244)

Given the number of employees or business actors who have not achieved their goals properly, or have not gotten results that are in accordance with the needs of human resources, the authors will discuss further the role of human resources in this study, especially in the field of Small and Medium Enterprises (SMEs), namely the case of Home SMEs. Tenda Biru Restaurant.

According to the Decree of the President of the Republic of Indonesia no. 99 of 1998 the definition of Small Business is "small-scale people's economic activities with business fields which are the majority of small business activities and need to be protected to prevent unfair business competition." (Wikipedia, 2021)

Small and medium enterprises are people's economic activities that have a net worth of at most Rp. 200.000.000,- excluding land and buildings for business premises. Or those with annual sales of at most Rp. 1.000.000.000 and belongs to Indonesian citizens. (Kwartono, 2007, p. 12)

The small and medium businesses that the author is currently researching are small and medium businesses that are engaged in the culinary field, especially in Deli Serdang Regency, precisely in Galang District. In Galang City, there are many types of small and medium businesses that were founded by the surrounding community, and mostly engaged in the culinary field. As an example of the Blue Tent Restaurant business, the owner of this business opened this business to develop his ability in doing business such as selling or serving Javanese and Minang specialties, such as curry chicken, grilled chicken, fried chicken, sambal chicken, grilled bloated fish, green chili catfish, mayung fish head curry, carp arsik, and so on, there are also other types of small and medium businesses, namely selling children's snacks, toys, and many other examples around 
us. Businesses like this can develop and will mushroom in the surrounding community, reducing unemployment.

Revenue is income that arises from the normal course of the entity's activities and is known by different names, such as sales, rendering of services, interest, dividends, royalties and rent. (Indonesia, 2015, p. 231)

Consumer behavior is the study of how individuals, groups and organizations select, purchase, use and dispose of goods, services, ideas or experiences to satisfy their wants and needs. (Kotler \& Keller, 2010, p. 166)

From the above background, this study aims to see how much influence human resources have on the income of small and medium-sized businesses at Blue Tent Restaurant, the problems faced in running the Blue Tent Restaurant business, and analysis of consumer behavior in small and medium businesses Blue Tent Restaurant.

\section{B. Method}

The data used in this study include primary data and secondary data. The primary data of this study were obtained from direct interviews with business owners, 6 employees, and 93 consumers at the Blue Tenda Restaurant. while secondary data is obtained from small and medium business owners, while the form of the data is in the form of documents or archives owned by these small and medium businesses. In this study using qualitative data analysis consisting of data reduction, data presentation, and drawing conclusions.

\section{Results and Discussion}

\section{The Influence of Human Resources on Small and Medium Enterprises Income}

From the results of this study, human resources have a positive influence in increasing the income of the Blue Tent Restaurant Business. The things that have a positive influence in improving the Blue Tent Restaurant are, firstly the cuisine, the beginning of the establishment of the blue tent restaurant in 1999, which is located on the front of the shop which only uses a blue tent as a roof and only provides a few tables and chairs. Tthe business owner employs two members in the field of cooks with elementary school education. Then in 2001 the Blue Tent Restaurant moved and had a permanent place, the business owner still retains the two cooks until now, the reason the business owner keeps the cook is because it is seen from the experience of their age of work experience who has worked in the field for 22 years. cook cooking. The higher 
the experience of working age, the better the performance given by the cook to the Blue Tent Restaurant, it can be seen from the consistency of the cook to the taste of the food provided, from the past until now the taste of the Blue Tent Restaurant has not changed, and continues experienced an increase in income. Most of the consumers in the respondents who obtained $48 \%$ stated that the taste of food that has not changed from the past until now is the main key for them to return to eating at the Blue Tenda Restaurant.

The second thing that has a positive influence in improving the Blue Tent Restaurant is in the cleanliness section. At the beginning of the establishment of the Blue Tent Restaurant the cleanliness was not maintained, at that time the employees employed by the owner were junior high school (SMP) graduates, due to poor performance the business owner did not hire him anymore, it also coincided with the change of the location of the blue tent restaurant and the location This new project is very strategic, so the owner employs employees who graduated from high school (SMA). As long as the owner employs employees who graduated from High School (SMA), the cleanliness of the Blue Tent Restaurant is very well maintained, that's because the Blue Tent Restaurant employees are very diligent and they always come to work. Most of the consumers in the respondents who got $25 \%$ stated that cleanliness was the reason for consumers to visit the Blue Tent Restaurant, because current employees always maintain the cleanliness of the Blue Tent Restaurant.

The third thing that has a positive influence in increasing the business income of the Blue Tent Restaurant is in the service section. At the beginning of the establishment of the Blue Tent Restaurant, the service part was carried out by the relatives of the restaurant owner who graduated from Junior High School (SMP), because his performance was not good, the Blue Tent Restaurant owner did not hire him anymore. Then the owner recruits employees who graduated from high school (SMA), this is done by the owner because the new location is a good place, so many people from various backgrounds eat at the Blue Tent Restaurant. When the owner employs employees who graduated from high school (SMA), consumers feel satisfied and comfortable eating at Blue Tent Restaurant, because current employees are very friendly to consumers. business owners feel that there is a change in income compared to the past with the current one. So that most of the consumers in the respondents who got $15 \%$ stated that the services provided by the employees of the Blue Tent Restaurant were very good. 
The fourth thing that has a positive influence in increasing the income of the Blue Tent Restaurant is the parking space provided by the owner of the Blue Tent Restaurant. The parking space provided by the business owner of the Blue Tent Restaurant is very wide, making it easier for consumers to park their vehicles properly. Some of the consumers in the respondents who were found $12 \%$ stated that the large parking lot was the reason they visited.

At the beginning of the establishment of the Blue Tent Restaurant which only used tents, the business owner only employed employees who graduated from Elementary School (SD) and Junior High School (SMP), the gross income received by the business owner at that time was RP. 60.000.000/month. While the income received by the owner of the Blue Tent Restaurant while employing employees who graduated from high school (SMA) is Rp. 105.000.000/month. The difference in income from the beginning of the establishment of the Blue Tent Restaurant with now is as much as Rp. 45.000.000. This means that there is an increase in income when business owners hire employees who have graduated from high school.

\section{Problems Faced In Running The Blue Tent Restaurant Business}

The following are the problems faced in running the blue tent restaurant business and how to overcome them:

\section{a. PPH Expense}

The high payment of taxes (income tax) makes business owners feel objected because the owner does not charge tax payments to his consumers directly, but from the income he receives. Tax payments are made once a year by distributing monthly income multiplied by $10 \%$. PPH payments are excluded from gross income, can be detailed, namely: Rp. 105.000 .000 times $10 \%$ of PPH that must be paid by blue tent restaurants amounting to Rp. 10.500.000, so the remaining gross income after PPH payment of Rp. 94.500.000.

\section{b. Revenue Decreases During Pandemic}

During the covid-19 pandemic, income at Blue Tent Restaurants decreased. Early before the pandemic Rumah Makan Tenda Biru had a gross income of Rp. 135.000.000 per month, but in the pandemic the gross income received by business owners became Rp.105.000.000 per month. There was a decrease in revenue from before and during the pandemic of Rp. 30.000.000. As for the way of countermeasures carried out by restaurant owners to maintain their business during the pandemic, namely by reducing the number of servings of cuisine, so it is predicted enough for a day. The owner still 
provides the best service, maintaining the taste with the usual seasoning provided by the cook. Restaurant owners hope that by the time the pandemic is over, the income of the Blue Tent Restaurant will improve again.

\section{Consumer behavior}

Consumers in Blue Tent Restaurants are very diverse, from teenagers, to adults, most of the respondents of Blue Tent Restaurants are regular consumers, namely consumers who have subscribed and always buy at Blue Tent Restaurants.

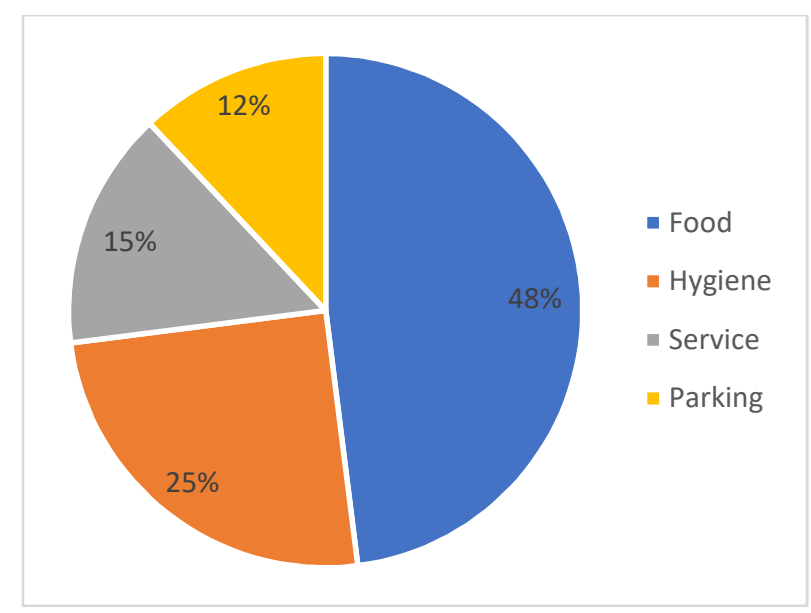

Consumer Satisfaction Graph

Based on the results of the study, most consumers still stated that $48 \%$ of food was the main factor they ate at the Blue Tent Restaurant, followed by the majority of permanent consumers and a small percentage of consumers did not still state $25 \%$ cleanliness to be the reason they ate at the Blue Tent Restaurant, followed by most consumers still stated $15 \%$ of the services provided by Blue Tent Restaurants to be their convenience to eat at the Blue Tent Restaurant, Most consumers do not still state that the $12 \%$ of parker's spacious premises make their reason to visit the Blue Tent Restaurant.

\section{Conclusion}

The results showed that, the location of human resources is very influential on the income of small and medium-sized businesses, by employing employees of graduates of High School (SMA) this business is able to reap profits of Rp. 105.000.000/month or Rp. 3.500.000 per day, when compared to when their employees graduated from Junior High School (SMP), the turnover obtained was only Rp. 60.000.000/month. In the time of the pandemic, there was a decrease in income, where before the pandemic profits reached 
Rp. 135.000.000/month. The obstacle experienced is the high PPH burden and must be paid every year for Rp 10.500.000. An analysis of consumer behavior states that $48 \%$ of consumers choose food as the main reason to visit the Blue Tent Restaurant, $25 \%$ choose cleanliness, $15 \%$ choose service and $12 \%$ choose a vehicle parker place.

\section{Bibliography}

Elbadiansyah. (2019). Manajemen Sumber Daya Manusia. Malang: IRDH.

Hasibuan. (2003). Manajeman Sumber Daya Manusia. Jakarta: Bumi Aksara.

Indonesia, I. A. (2015). Standar Akuntansi Keuangan ETAP. Jakarta: Ikatan Akutan Indonesia.

Kotler, P., \& Keller, K. L. (2010). Manajemen Pemasaran (13 ed.). Jakarta: Erlangga.

Kwartono, M. (2007). Analisis Usaha Kecil dan Menengah. Yogyakarta: CV. Andi Offset.

Sumarsono, S. (2003). Ekonomi Manajemen Sumber Daya Manusia Dan Ketenagakerjaan. Yogyakarta: Graha IImu.

Wikipedia. (2021, September 25). Usaha Kecil Dan Menengah Usaha_Kecil_dan_Menengah, (diaksestanggal 11 Mei 2020). Retrieved Mei 11, 2021, from Wikipedia: https://id.wikipedia.org/wiki/ 